\title{
ASPEK BIOKULTURAL SISA RANGKA MANUSIA DARI SITUS LIANGAN, TEMANGGUNG, JAWA TENGAH
}

\section{BIOCULTURAL ASPECT OF HUMAN REMAIN FROM LIANGAN SITE, TEMANGGUNG, CENTRAL JAVA}

\author{
Sofwan Noerwidi \\ Balai Arkeologi Yogyakarta \\ noerwidi@arkeologijawa.com
}

\begin{abstract}
In 2013, Center for Archaeological Research of Yogyakarta has found a human remain in Cluster F, Liangan site, Temanggung, which named as individual of Liangan F1. This study tries to reveals biological and cultural aspects which recorded on this remain by bioarchaeological approach. Biological aspects are including; age estimation, sex determination, population affinity, and pathology or health condition. Meanwhile, cultural aspects are including antemortem cultural practice which associated to dental modification, and perimortem taphonomy as evidence of funeral practices or burial procedures. Study on human remains from Liangan settlement site of Ancient Mataram Kingdom has opened our knowledge to understanding culture and human behavior which develop during the historical period of $9^{\text {th }}-10^{\text {th }}$ century $A D$ in Java.
\end{abstract}

Keyword : Biocultural Aspect, Human Remain, Old Mataram, Liangan

\section{ABSTRAK}

Pada tahun 2013, Balai Arkeologi Yogyakarta menemukan sisa rangka manusia di Kluster F situs Liangan, Temanggung, yang kemudian dinamakan individu Liangan F1. Penelitian ini berusaha mengungkap aspek biologis dan kultural yang terekam pada individu Liangan F1 dengan menggunakan pendekatan bioarkeologi. Aspek biologis yang diungkap mencakup estimasi usia, penentuan jenis kelamin, afinitas populasi, dan patologi atau kondisi kesehatan. Sedangkan aspek budaya mencakup kebiasaan modifikasi pada saat antemortem yang terkait dengan gigi, dan bukti tafonomi perimortem seperti praktek pemakaman atau tata cara penguburan. Studi sisa rangka manusia dari situs permukiman Mataram Kuna-Liangan ini telah membuka cakrawala kita dalam memahami budaya dan pola tingkah laku manusia yang berkembang pada masa Klasik abad 9 - 10 M di Jawa.

Kata Kunci : Aspek Biokultural, Rangka Manusia, Mataram Kuna, Liangan

Tanggal masuk : 11 Januari 2016

Tanggal diterima : 31 Mei 2016 


\section{PENDAHULUAN}

Situs permukiman Mataram Kuna di Liangan secara administratif terletak di Dusun Liangan, Desa Purbosari, Kecamatan Ngadirejo, Kabupaten Temanggung. Secara geografis, situs ini terletak di lereng tengah sebelah timur laut Gunung Sindoro pada ketinggian di antara 1.100-1.200 meter dpl. Indikasi keberadaan situs Liangan pertama kali dilaporkan oleh seorang warga kepada Balai Arkeologi Yogyakarta pada tahun 2000, yang menemukan susunan memanjang balok-balok batu (Rangkuti dan Tjahjono, 2000). Namun, setelah berita penemuan tersebut situs Liangan seperti "dilupakan" oleh para peneliti.

Penelitian intensif di situs Liangan baru dimulai sejak tahun 2008, setelah ditemukan struktur talud, komponen batu candi, dan arca akibat aktivitas penambangan yang terletak lebih ke sebelah hulu, tidak jauh dari lokasi penemuan pada tahun 2000. Signifikansi situs Liangan semakin jelas setelah ditemukannya bangunan candi pada tahun 2009. Secara umum berdasarkan hasil penelitian Balai Arkeologi Yogyakarta, dapat diketahui bahwa situs Liangan merupakan situs permukiman yang kompleks dan menempati area luas

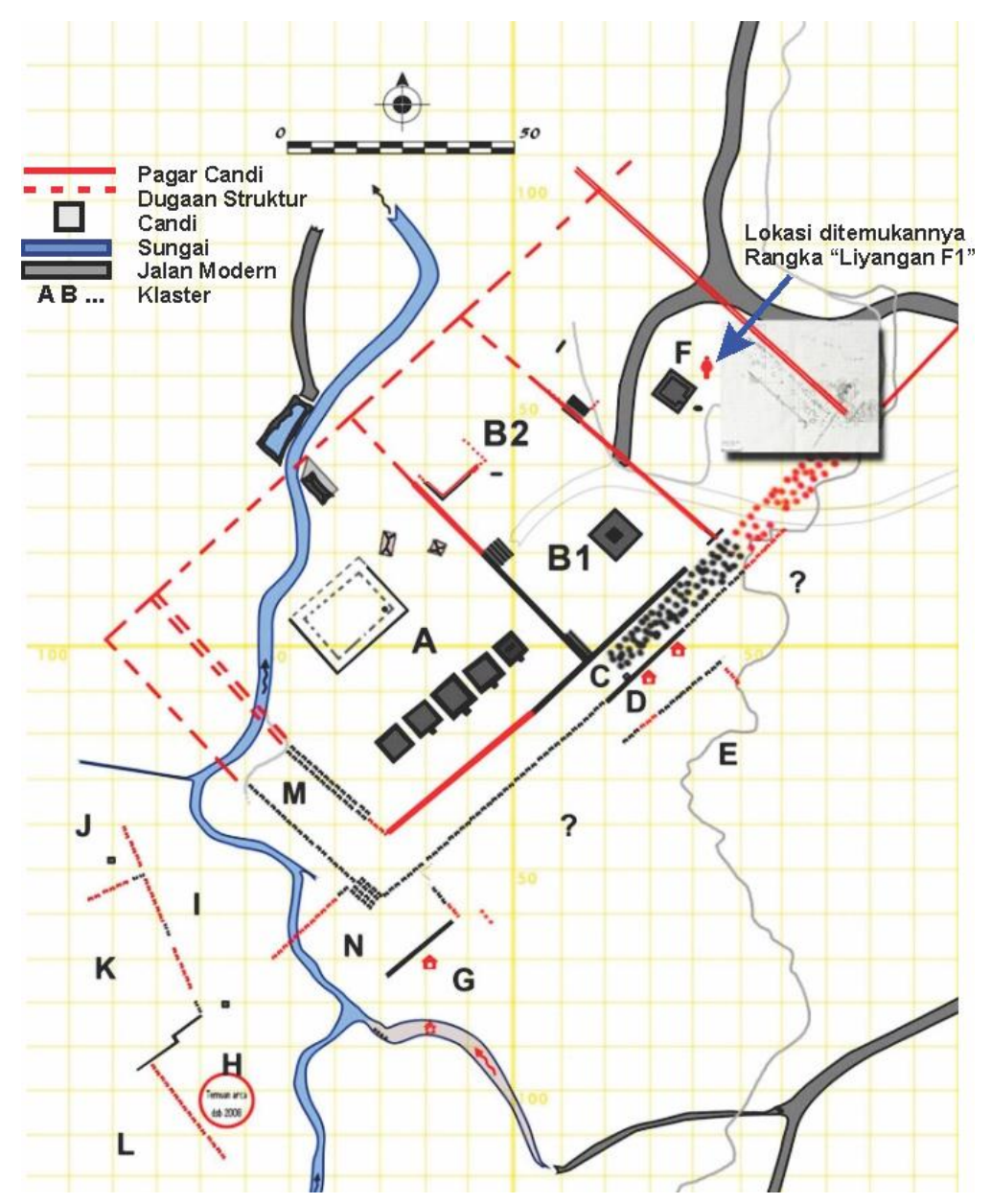

Gambar 1. Lokasi Penemuan Sisa Manusia di Situs Liangan, Kluster F (Dok. Tim Penelitian, 2013) 
yang terdiri atas; area peribadatan, area hunian, dan area pertanian. Berdasarkan bukti-bukti pertanggalan relatif dan absolut, situs Liangan ditempatkan pada kerangka kronologi masa Mataram Kuna, sekitar kurun abad 9 - 10 Masehi (Riyanto, 2011).

telah $\begin{gathered}\text { Pada tanggal } \\ \text { dilakukan }\end{gathered} \quad \begin{aligned} & \text { Juli } 2013 \\ & \text { kegiatan }\end{aligned}$ penyelamatan sisa rangka manusia di situs permukiman Mataram Kuna, Liangan yang dilakukan oleh Siswanto dan Sugeng Riyanto dari Balai Arkeologi Yogyakarta. Kegiatan ini berhasil mengumpulkan, untuk kemudian menyelamatkan satu matrik sisa rangka manusia yang kemungkinan besar berasal perlapisan pengendapan batuan di sekitarnya yang didominasi oleh pasir krikilan, materi hasil sedimentasi lahar dingin gunung api Sindoro (Gambar 2). Berdasarkan konteksnya, fitur (kubur ?) manusia ini berkedudukan pada ketinggian yang sama dengan tanah permukaan pondasi bangunan yang ada di sebelahnya. Hal ini mengindikasikan bahwa fitur tersebut berasal dari rentang budaya yang sejaman dengan permukiman Mataram Kuna Liangan, sekitar abad 9-10 Masehi.

Hingga saat ini masih sedikit temuan rangka manusia dari periode klasik (Hindu-Buddha) di Indonesia. Dengan penemuan ini membuat sisa
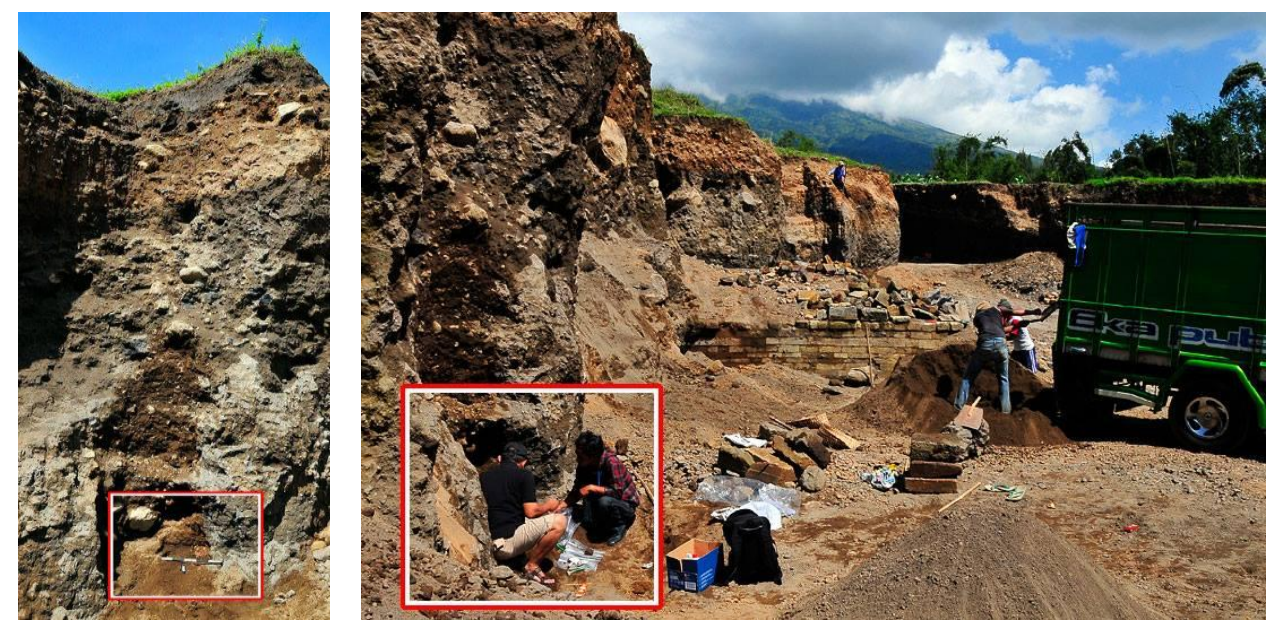

Gambar 2. Penemuan Individu Liangan F1 di Lokasi Penambangan Pasir

(Dok. Tim Penelitian, 2013)

dari suatu fitur penguburan. Untuk kepentingan identifikasi, maka sisa rangka tersebut diberi nama individu "Liangan F1", yang berarti rangka manusia dari situs Liangan, ditemukan di Kluster F (lihat Gambar 1 ), dengan nomer urut individu 1.

Sisa manusia ini ditemukan dalam suatu matrix tanah lempung pasiran berwarna coklat kehitaman, yang merupakan ciri tanah organik (paleosol). Matrix tersebut membentuk suatu fitur yang bentuknya tidak selaras dengan manusia dari situs Liangan memiliki kedudukan yang cukup penting untuk mengungkap aspek biokultural kehidupan masyarakat pada masa Jawa Kuna.

\section{METODE DAN TEKNIK ANALISIS}

Penelitian ini menggunakan metode bioarkeologi, yaitu studi mengenai sisa rangka manusia yang berasal dari konteks arkeologi (White dan Folkens, 2005). Metode ini dipilih karena rangka manusia 
yang dipelajari berasal dari situs arkeologis permukiman Mataram Kuna - Liangan. Sifat penelitian dalam tulisan ini adalah deskriptif analitis, yang berusaha mendeskripsikan karakter morfologi dan morfometri yang masih tersisa dari rangka manusia Liangan untuk kemudian dianalisis dengan pendekatan-pendekatan dalam bioarkeologi.

Aspek-aspek yang dibahas dalam tulisan ini adalah aspek biokultural, yang meliputi aspek biologis dan aspek kultural. Pembahasan aspek biologis mencakup estimasi usia, penentuan jenis kelamin, afinitas populasi, dan patologi atau kondisi kesehatan. Pembahasan konteks budaya akan fokus pada modifikasi budaya pada saat antemortem yang terkait dengan gigi, dan bukti budaya perimortem seperti praktek pemakaman atau tata cara penguburan (White dan Folkens, 2005). Proses tafonomi postmortem tidak akan dibahas dalam tulisan ini, karena spesimen Liangan F1 ditemukan pada suatu lokasi penambangan pasir yang lokasinya kini telah hancur, sehingga sejarah tafonomi yang terekam pada stratigrafi tidak memungkinkan untuk dilakukan analisis tafonomi kubur secara detil.

\section{DESKRIPSI SISA MANUSIA}

Secara umum, kondisi sisa manusia individu Liangan F1 sangat rapuh sehingga menyulitkan proses identifikasi. Secara garis besar, sisa manusia ini terdiri dari fragmen tulang cranium (tengkorak) dan postcranium. Berikut ini adalah deskripsi sisa manusia tersebut, yaitu:

\section{Tengkorak}

Sisa tengkorak kondisinya sangat rapuh, bagian yang dapat diamati adalah endocranial, sedangkan bagian ectocranial masih terbungkus matrix (Gambar 3). Terdapat dua tulang yang dapat diamati yaitu fragmen bagian superior tulang occipital dan fragmen bagian posterior tulang parietal kanan yang keduanya masih disatukan dengan lamdoidal suture.

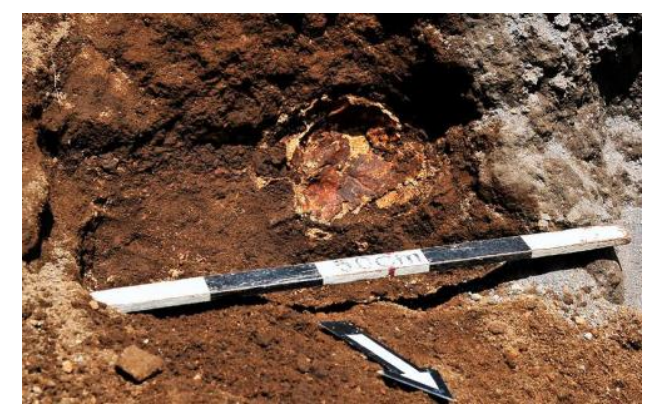

Gambar 3. Kondisi pada saat Penemuan Fragmen Tengkorak

(Dok. Tim Penelitian, 2013)

\section{a. Occipital}

Karakter yang dapat diamati pada bagian endocranial dari tulang occipital ini adalah cerebral fossa yaitu jejak perlekatan jaringan otak, dan transversal sulcus yaitu cekungan lokasi tonjolan tulang occipital.

\section{b. Parietal kanan}

Pada bagian endocranial tulang parietal, jejak cerebral fossa agak sulit diamati karena kondisi tulang yang sangat rapuh, dan terbungkus lapisan treatment penguat yang diaplikasikan pada saat proses pengangkatan tulang.

\section{Gigi-geligi}

Sampai saat ini telah ditemukan sebanyak 16 gigi lepas yang berasal dari individu Liangan F1. Kondisi umum gigi geligi tersebut sangat rapuh khususnya pada bagian akar gigi (Gambar 4). Berdasarkan hasil identifikasi dapat diketahui bahwa sebagian besar gigi-geligi yang ditemukan tersebut merupakan gigi maxilla (rahang 
atas), dan hanya satu canine sebelah kiri yang berasal dari mandible (rahang bawah). Hasil identifikasi pada material tersebut antara lain adalah:

a. I $^{1}$ sup dex: kondisinya cukup baik, banyak diselimuti karang gigi (dental calculus). Kemungkinan juga terdapat jejak pangur pada bidang occlusal, palatal dan labial. Pada bidang tersebut mungkin juga terdapat jejak perforasi.

b. $\mathrm{I}^{2}$ sup dex: kondisinya cukup baik, banyak diselimuti karang gigi (dental calculus). Kemungkinan juga terdapat jejak pangur pada bidang palatal dan labial, namun tidak ditemukan pada bidang occlusal.

c. $\mathrm{I}_{1}$ inf $\sin$ dan dex: kondisinya cukup baik, banyak diselimuti karang gigi (dental calculus). Kemungkinan juga terdapat jejak pangur hanya pada bidang occlusal saja.

d. C sup dex: terdapat primping gigi, dan patah pada bagian akar gigi

e. C inf sin: kemungkinan terdapat jejak pangur miring, dan patah pada bagian akar gigi

f. $\mathrm{PM}^{3}$ sup sin dan dex: kondisinya cukup baik, namun patah pada bagian akar gigi

g. $\mathrm{PM}^{4}$ sup sin dan dex: kondisinya cukup baik, namun patah pada bagian akar gigi

h. $\mathrm{M}^{1}$ sup sin dan dex: Bagian enamel telah aus hingga meratakan tonjolan cuspic-nya. Juga terdapat lubang karies gigi pada bidang cone yang masuk hingga bagian dentin.

i. $\mathrm{M}_{1}$ inf sin: Bagian enamel telah aus hingga meratakan beberapa tonjolan cuspic-nya. Juga terdapat lubang karies gigi yang cukup lebar pada bidang cone yang masuk hingga bagian dentin.

j. $\mathrm{M}^{2}$ sup dex: Bagian enamel sedikit aus pada tonjolan cuspicnya, selain itu juga terdapat rekahan awal terbentuknya karies gigi di lembah antara cone.

k. $\mathrm{M}^{3}$ sup sin: Bagian enamel utuh, namun bagian dentin telah hancur. Kemungkinan belum erupsi karena sama sekali belum menunjukan tanda-tanda penggunaan. Selain itu, akar gigi juga menunjukan pertumbuhan yang belum sempurna.

I. $\mathrm{M}_{3}$ inf sin: Bagian enamel utuh. Kemungkinan belum erupsi karena sama sekali belum menunjukan tanda-tanda penggunaan. Akar gigi sudah mulai menunjukan pertumbuhan, walaupun nampaknya belum sempurna.

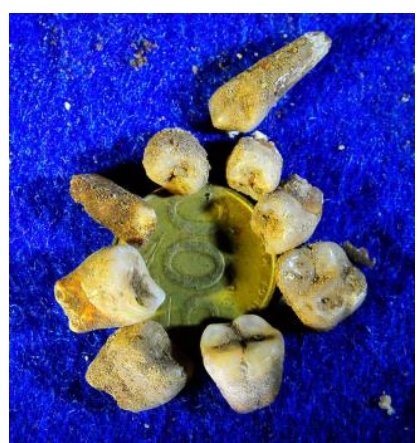

Gambar 4. Gigi-geligi Individu Liangan F1 (Dok. Tim Penelitian, 2013)

Setelah dilakukan deskripsi berdasarkan pengamatan umum, juga dilakukan observasi karakterkarakter khusus pada gigi individu Liangan $\mathrm{F} 1$ yang berguna sebagi bahan acuan penilaian afiliasi individu tersebut dengan populasi manusia di kawasan sekitarnya. 15 variabel gigi-geligi (Tabel 1) yang digunakan dalam penelitian ini mengacu pada Matsumura dan Oxenham (2014). 
Tabel 1. Karakter Gigi-geligi Individu Liangan F1 berdasarkan variabel NonMetrik

\begin{tabular}{|c|c|c|c|c|}
\hline No. & Karakter & Gigi & Referensi & Individu Liangan F1 \\
\hline 1. & Dental shoveling & $\mathrm{I}^{1}$ dan $\mathrm{I}^{2}$ & Hanihara, et.al., 1970 & $\begin{array}{l}\text { Kedua gigi Incisive memiliki } \\
\text { shovel shape yang cukup } \\
\text { nyata }\end{array}$ \\
\hline 2. & Double shoveling & $\mathrm{I}^{1}$ dan $\mathrm{I}^{2}$ & $\begin{array}{l}\text { Suzuki dan Sakai, } \\
1973\end{array}$ & $\begin{array}{l}\text { Tidak dapat diamati karena } \\
\text { ablasi pada bagian labial }\end{array}$ \\
\hline 3. & Dental tubercle & $\mathrm{I}^{1}$ dan $\mathrm{I}^{2}$ & Turner, et.al., 1991 & $\begin{array}{l}\mathrm{I}^{2} \text { memiliki dental tubercle } \\
\text { yang kurang nyata }\end{array}$ \\
\hline 4. & Dental Spine & $\mathrm{I}^{1}$ & Dahlberg's P-plaque & Tidak memiliki dental Spine \\
\hline 5. & $\begin{array}{l}\text { Interruption } \\
\text { groove }\end{array}$ & $\mathrm{I}^{2}$ & Turner, et.al., 1991 & $\begin{array}{l}\text { Sulit diamati karena tertutup } \\
\text { oleh dental kalkulus }\end{array}$ \\
\hline 6. & Dental winging & $\mathrm{I}^{1}$ & $\begin{array}{l}\text { Enoki dan Dahlberg, } \\
1958\end{array}$ & $\begin{array}{l}\text { Tidak dapat diamati karena } \\
\text { telah lepas dari maxilla }\end{array}$ \\
\hline 7. & $\begin{array}{l}\text { De Terra's } \\
\text { Tubercle }\end{array}$ & $\mathrm{P}^{1}$ & Saheki, 1958 & $\begin{array}{l}\text { Tidak memiliki De Terra's } \\
\text { Tubercle }\end{array}$ \\
\hline 8. & Double roots & $\mathrm{P}^{1}$ dan $\mathrm{P}^{2}$ & Turner, et.al., 1991 & $\begin{array}{l}\text { Berdasarkan pengamatan pada } \\
\text { pulpa, kemungkinan memiliki } \\
\text { double roots }\end{array}$ \\
\hline 9. & Carabelli's trait & $M^{1}$ & Dahlberg's P-plaque & $\begin{array}{l}\text { Tidak memiliki carabelli's } \\
\text { trait }\end{array}$ \\
\hline 10. & $\begin{array}{l}\text { Hypocone } \\
\text { reduction }\end{array}$ & $\mathrm{M}^{2}$ & Dahlberg's P-plaque & $\begin{array}{l}\text { Terdapat indikasi reduksi } \\
\text { hypocone }\end{array}$ \\
\hline 11. & Sixth cusp & $\mathrm{M}_{1}$ & Turner, et.al., 1991 & $\begin{array}{l}\text { Terdapat sixth cusp yang } \\
\text { sangat nyata }\end{array}$ \\
\hline 12. & Seventh cusp & $\mathrm{M}_{1}$ & Turner, et.al., 1991 & $\begin{array}{l}\text { Nampak jejak seventh cusp } \\
\text { yang tidak terlalu nyata }\end{array}$ \\
\hline 13. & Protostylid & $\mathrm{M}_{1}$ & Dahlberg's P-plaque & Tidak memiliki protostylid \\
\hline 14. & Deflecting wrinkle & $\mathrm{M}_{1}$ & Turner, et.al., 1991 & $\begin{array}{l}\text { Kemungkinan memiliki } \\
\text { deflecting wrinkle, namun } \\
\text { jejaknya tersamar oleh atrisi } \\
\text { pada bidang occlusal }\end{array}$ \\
\hline 15. & Groove pattern $Y$ & $\mathrm{M}_{1}$ & Jørgensen (1955) & $\begin{array}{l}\text { Memiliki pola berbentuk Y } \\
\text { pada bidang occlusal }\end{array}$ \\
\hline
\end{tabular}

Sumber: Matsumura dan Oxenham, 2014

\begin{tabular}{llr}
\multicolumn{2}{c}{ Selain dilakukan studi } \\
morfologi seperti yang telah \\
dilakukan di atas, kemudian
\end{tabular} dilakukan studi morfometri pada gigigeligi individu Liangan F1. Studi ini berguna untuk menguatkan penilaian afiliasi individu tersebut dengan populasi manusia di kawasan sekitarnya. Dua variabel yang digunakan untuk studi morfometri tersebut adalah :

a. MD : pengukuran jarak maksimal mesial - distal pada posisi anatomis, dalam millimeter

b. $\quad \boldsymbol{B} L$ : pengukuran jarak maksimal buccal - lingual pada posisi anatomis, dalam millimeter Pengukuran tersebut diaplikasikan pada seluruh gigi-geligi yang tersisa, baik gigi atas maupun gigi bawah. Berikut ini adalah hasil pengukuran tersebut :

a. Gigi Atas Liangan F1 (Tabel 2) 
Tabel 2. Hasil Pengukuran Gigi-geligi Rahang Atas Individu Liangan F1

(dalam Milimeter)

\begin{tabular}{|l|c|c|c|c|c|c|c|c|c|c|c|}
\hline & $\begin{array}{c}\mathbf{I}^{1} \\
\text { dex }\end{array}$ & $\begin{array}{c}\mathbf{I}^{2} \\
\text { dex }\end{array}$ & $\begin{array}{c}\mathbf{C} \\
\text { dex }\end{array}$ & $\begin{array}{c}\mathbf{P M}^{3} \\
\text { sin }\end{array}$ & $\begin{array}{c}\mathbf{P M}^{3} \\
\text { dex }\end{array}$ & $\begin{array}{c}\mathbf{P M}^{4} \\
\text { sin }\end{array}$ & $\begin{array}{c}\mathbf{P M}^{4} \\
\text { dex }\end{array}$ & $\begin{array}{c}\mathbf{M}^{1} \\
\text { sin }\end{array}$ & $\begin{array}{c}\mathbf{M}^{1} \\
\text { dex }\end{array}$ & $\begin{array}{c}\mathbf{M}^{2} \\
\text { dex }\end{array}$ & $\begin{array}{c}\mathbf{M}^{3} \\
\text { sin }\end{array}$ \\
\hline MD & 6.55 & 6.00 & 8.00 & 7.93 & 7.95 & 7.40 & 7.35 & 12.13 & 11.55 & 9.85 & 11.95 \\
\hline BL & 7.40 & 6.70 & 8.35 & 9.75 & 9.68 & 8.00 & 9.55 & 11.45 & 11.80 & 11.50 & 10.00 \\
\hline
\end{tabular}

Sumber : Analisis Penulis

b. Gigi Bawah Liangan F1 (Tabel 3)

Tabel 3. Hasil Pengukuran Gigi-geligi Rahang Bawah Individu Liangan F1 (dalam Milimeter)

\begin{tabular}{|l|l|l|l|l|l|}
\hline & $\mathbf{I}_{\mathbf{1}} \sin$ & $\mathbf{I}_{1}$ dex & $\mathrm{C}_{\text {sin }}$ & $\mathbf{M}_{\mathbf{1}} \sin$ & $\mathbf{M}_{\mathbf{3}} \sin$ \\
\hline $\boldsymbol{M D}$ & 5.70 & 5.75 & 7.50 & 11.65 & 11.80 \\
\hline $\boldsymbol{B L}$ & 6.30 & 6.25 & 7.70 & 10.70 & 10.50 \\
\hline
\end{tabular}

Sumber: Analisis Penulis

Variable yang didapat dari pengukuran morfometri tersebut di atas kemudian diolah dengan menggunakan analisis multivariate statistik, yang akan dibahas dalam bagian selanjutnya (Afinitas Populasi). Perangkat lunak yang digunakan untuk mengolah data morfometri dalam tulisan ini adalah PAST (PAleontological STatistic software package for education and data analysis) versi 2.13, yang merupakan perangkat lunak bersifat tanpa bayar (open source) khusus dikembangkan untuk mengolah data statistik dalam arkeologi (Hammer et.al., 2011).

\section{Tulang panjang}

Dari materi tersisa terdapat empat tulang panjang, namun satu diantaranya belum dapat dipisahkan karena masih berada dalam matrik, dan menempel dengan tulang tengkorak. Keempat tulang panjang tersebut terdiri dari dua femur, dan 2 tulang yang tidak dapat diidentifikasi karena keterbatasan karakter yang terkonservasi sebagai parameter pengamatan. Dua tulang panjang yang dapat diidentifikasi tersebut adalah:

\section{a. Femur kiri}

Femur kiri tersisa hanya bagian diaphysis saja, sedangkan kedua epiphysis proximal dan distal telah hancur sehingga menyulitkan identifikasi. Pada bagian anterior medial terdapat jejak tafonomi berupa deformasi yang terjadi diantara post mortem dan proses retrieval (penemuan kembali). Perlu pengamatan lebih lanjut untuk mengetahui penyebab tafonomi tersebut, apakah karena faktor biotis atau abiotis.

Pada bagian posterior proximal beberapa karekter yang masih dapat diamati, antara lain adalah: pectineal line, gluteal line, dan linea aspera yang cukup nyata, sedangkan nutrient foramen tidak dapat diamati karena kondisi preservasi yang kurang baik. Kemudian pada bagian posterior distal karekter yang dapat diamati adalah: nutrient foramen, serta bagian flat (dataran) di atas epiphysis distal atau disebut dengan popliteal surface yang dibatasi oleh medial dan lateral supracondylar line.

\section{b. Femurkanan}

Femur kanan kondisinya tidak sebaik femur kiri. Tulang ini hanya tersisa bagian diaphysis saja dan patah menjadi dua bagian pada bagian medial-nya. Sama seperti femur kiri, tulang ini juga telah kehilangan kedua epiphysis proximal dan distal-nya. Pada bagian anterior 
proximal juga terdapat jejak tafonomi.

Pada bagian posterior proximal tidak dapat diamati karena kondisi konservasi yang sangat buruk (Gambar 5). Sedangkan pada bagian posterior distal masih terdapat beberapa karakter yang dapat diamati, antara lain adalah: nutrient foramen, serta popliteal surface yang dibatasi oleh medial dan lateral supracondylar line.

Karena

kondisi konservasinya yang sangat buruk, maka tidak mungkin untuk dilakukan studi morfometri segmen-segmen pada fragmen kedua tulang femur tersebut. Sehingga tidak dapat dijadikan acuan untuk memperkirakan tinggi badan individu Liangan F1.

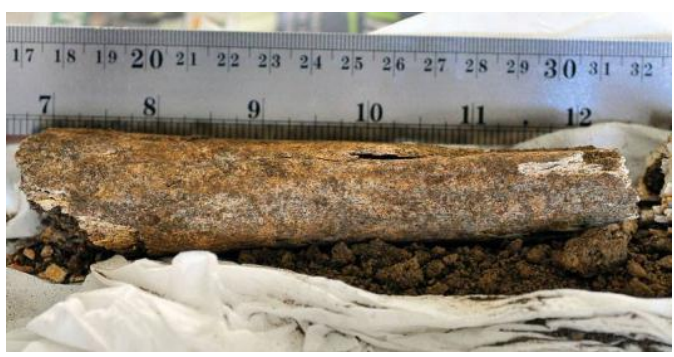

Gambar 5. Kondisi Diaphysis Femur Kanan Individu Liangan F1 yang Sangat

Fragmentaris (Dok. Balai Arkeologi Yogyakarta)

\section{ASPEK BIO-KULTURAL MANUSIA LIANGAN}

Berdasarkan hasil observasi karakter morfologi dan morfometri yang telah dilakukan pada bagian sebelumnya, maka langkah selanjutnya adalah melakukan analisis bioarkeologi guna mengidentifikasi aspek-aspek biokultural yang dimiliki oleh individu Liangan F1. Berikut ini adalah pembahasan aspek-aspek tersebut:

\section{Estimasi Usia}

Estimasi usia individu waktu meninggal dapat dilakukan berdasarkan observasi pada pertumbuhan dan atrisi (derajat penggunaan) gigi-geligi, serta perlekatan tulang-tulang tengkorak dan tulang-tulang panjang. Berdasarkan masih terbukanya suture pada tulang-tulang tengkorak, dan tidak terpreservasinya bagian epiphysis proximal dan distal tulangtulang panjang, maka diperkirakan bahwa individu Liangan F1 berusia muda.

Penentuan usia berdasarkan pada tingkat perkembangan dan atrisi gigi-geligi melalui metode Lovejoy (1985) dapat diketahui bahwa gigi maxilla individu Liangan F1 menunjukkan perkembangan tingkat $\mathrm{C}$, yaitu berusia sekitar 18-22 tahun. Pada tahap ini mahkota gigi molar terakhir (ke-3) telah berkembang dengan lengkap, namun belum menunjukkan jejak pemakaian, atau ada kemungkinan belum erupsi dengan sempurna (Gambar 6). Di lain pihak gigi molar pertama telah mengalami abrasi cukup signifikan sehingga meratakan cuspic-nya, sedangkan gigi molar kedua baru menunjukkan derajat pemakaian tingkat awal.

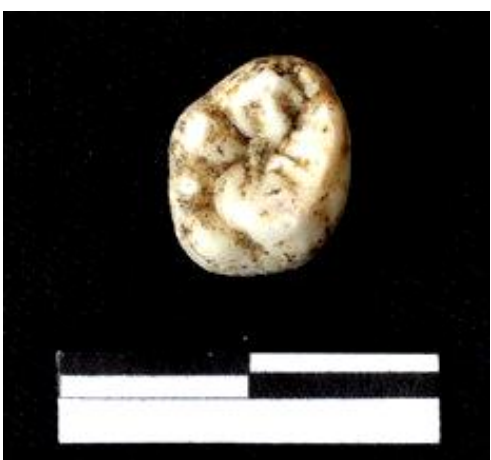

Gambar 6. Gigi Molar ke 3 individu Liangan F1 yang belum menunjukan jejak penggunaan (Dok. Balai Arkeologi Yogyakarta)

\section{Determinasi Sex}

Jenis Kelamin dari individu Liangan $\mathrm{F} 1$ belum dapat diketahui 
secara maksimal karena keterbatasan data yang dapat diobservasi, khususnya karena bagian-bagian tengkorak yang rapuh dan tidak adanya sisa tulang pelvis (pinggul) yang sangat signifikan bagi penentuan jenis kelamin. Berdasarkan pada ukuran gigi geligi yang kecil, jejak insersi otot-otot pada tulang panjang yang lemah, serta tonjolan tulang occipital pada bagian endocranial yang kurang nyata sehingga terkesan feminin, maka ada kemungkinan bahwa individu Liangan F1 berjenis kelamin perempuan. Namun, hipotesis ini masih harus dikonfirmasi oleh data pendukung lainnya yang lebih kuat seperti misalnya analisis genetika untuk membuktikan ada tidaknya $Y$ chromosome yang hanya diwariskan pada garis keturunan laki-laki.

\section{Patologi}

Kondisi kesehatan dan patologi (penyakit) yang dapat diamati pada individu Liangan F1 adalah terutama pada gigi-geliginya. Sebagian besar gigi tersebut, terutama gigi incisive mengalami penyakit dental calculus atau penumpukan karang gigi. Penyakit ini juga dapat memicu karies gigi (keropos), seperti yang ditunjukan oleh lubang pada molar atas pertama dan kedua (Gambar 7). Penyakit ini berhubungan dengan pola makan yang banyak mengandung gula, seperti biji-bijian (padi-padian) yang ekofaknya juga ditemukan di situs Liangan. Selain patologi dental caries dan dental calculus, juga terdapat jejak bruxism pada gigi canine atas yaitu perimping yang disebabkan karena kegiatan mengunyah yang terlalu keras.

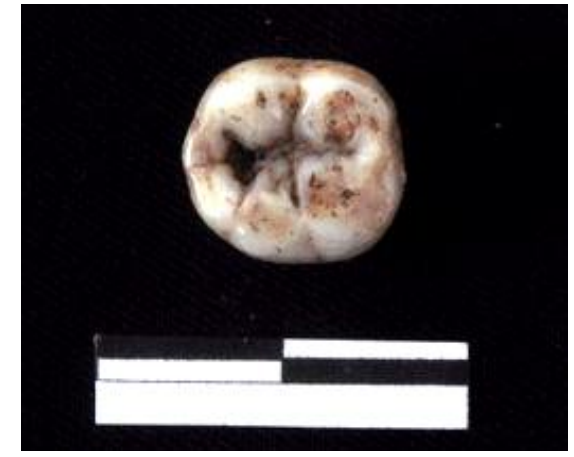

Gambar 7. Dental caries pada gigi Molar individu Liangan F1 (Dok. Balai Arkeologi Yogyakarta)

\section{Afinitas Populasi}

Penilaian kedekatan populasi dari individu Liangan F1 dapat dilakukan berdasarkan hasil observasi karakter morfologi pada gigi incisive atas, premolar atas, molar atas dan molar bawah. Afinitas populasi individu Liangan F1 berdasarkan penilaian pada karakter morfologi tersebut memiliki ciri rasial campuran yaitu karakter Mongoloid yang kuat dengan beberapa karakter Australo-Melanesid. Berikut ini beberapa komparasi karakter morfologi gigi individu Liangan F1 dengan data dari kawasan sekitarnya yang pernah dipublikasikan oleh Matsumura dan Oxenham (2014).

Pengamatan pada gigi incisive medial dan lateral atas dengan menggunakan metode Scott (1973) dapat diketahui bahwa individu Liangan F1 memiliki ciri ras Mongoloid, yang ditunjukan oleh shovel shape (bentuk sekop) yang sangat nyata pada bagian bucal gigi tersebut (Gambar 8, kiri). Di lain pihak, karakter shovel shape tidak ditemui pada populasi AustraloMelanesid (Matsumura dan Oxenham, 2014). Karakter double shoveling dan dental winging banyak ditemui pada populasi Mongoloid khususnya Amerindian, tidak dapat diamati pada individu Liangan F1 
karena sifat gigi yang isolated dan mengalami ablasi pada bagian labial. Pada individu ini terdapat jejak dental tubercle yang kurang nyata. Biasanya jejak tersebut banyak dimiliki oleh populasi Australo-Melanesid.

$$
\text { Interruption groove yang }
$$

biasanya dimiliki oleh populasi Mongoloid sulit diamati pada individu Liangan $\mathrm{F} 1$ karena tertutup oleh dental calculus. De Terra's tubercle dan Carrabelli's trait yang biasanya dijumpai pada populasi Mongoloid khususnya di kawasan Asia Timur dan bucco-lingual gigi $\mathrm{P}^{3}-\mathrm{M}^{2}$ saja yang dianalisis, karena biasanya ukuran gigi-geligi tersebut memiliki perbandingan khas yang dapat menunjukan perbedaan antar populasi (Noerwidi, 2012). Analisis statistik yang digunakan dalam studi ini adalah Cluster Analysis (CA), yaitu metode statistik yang berguna untuk merangkum probabilitas utama dalam pengelompokan populasi (Holland, 2006). Pada cluster analysis ini digunakan metode euclidean distance karena data yang digunakan adalah pada
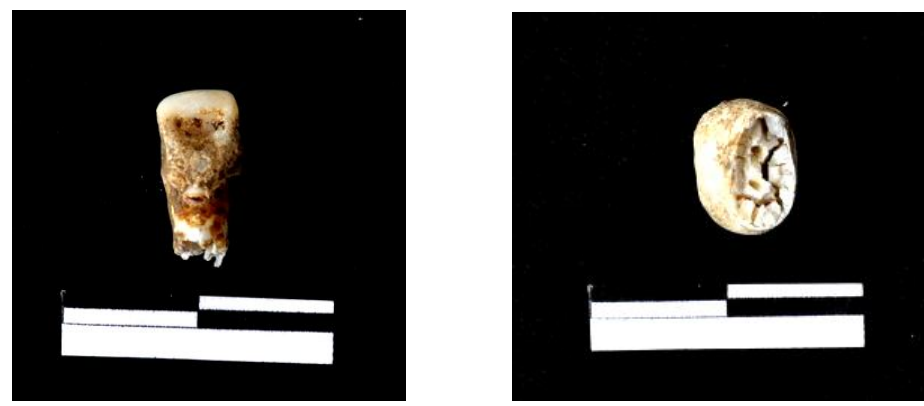

Gambar 8. Shovel shape incisor mewakili ciri Mongoloid (Kiri) dan Double root premolar mewakili ciri Australo-Melanesoid (Kanan). (Dok. Balai Arkeologi Yogyakarta)

Laut tidak dimiliki oleh individu Liangan F1. Hypocone reduction yang biasanya terdapat pada populasi Mongoloid khususnya dari kawasan Sub Arctic juga sedikit dimiliki oleh individu Liangan F1. Karakter sixth cusp dan deflecting wrinkle pada $\mathrm{M}_{1}$ yang merupakan ciri khusus populasi Mongoloid cukup jelas ditemukan pada individu Liangan F1. Di lain pihak, kemungkinan double root pada Premolar individu Liangan F1 biasanya ditemukan pada populasi Australo-Melanesid (Gambar 8, kanan).

Selain analisis berdasarkan karakter morfologi, juga dilakukan analisis terhadap morfometri gigigeligi. Pada studi ini dipilih hanya pengukuran maksimum mesio-distal raw data pengukuran gigi geligi mesio-distal dan bucco-lingual gigi $\mathrm{P}^{3}-\mathrm{M}^{2}$.

Berdasarkan

hasil pengelompokkan cluster analysis, dapat dikethui bahwa individu Liangan $\mathrm{F} 1$ berada di percabangan antara populasi Mongoloid di Asia Tenggara Kepulauan dan Daratan, dengan populasi AustraloMelanesoid di Pasifik dan Asia Tenggara Kepulauan (Gambar 9). Berdasarkan pada kedua teknik analisis tersebut, baik berdasarkan karakter morfologi maupun morfometri gigi-geliginya, dapat disimpulkan bahwa individu Liangan F1 memiliki karakter populasi Mongoloid yang kuat dengan campuran beberapa karakter Australo-Melanesoid. 


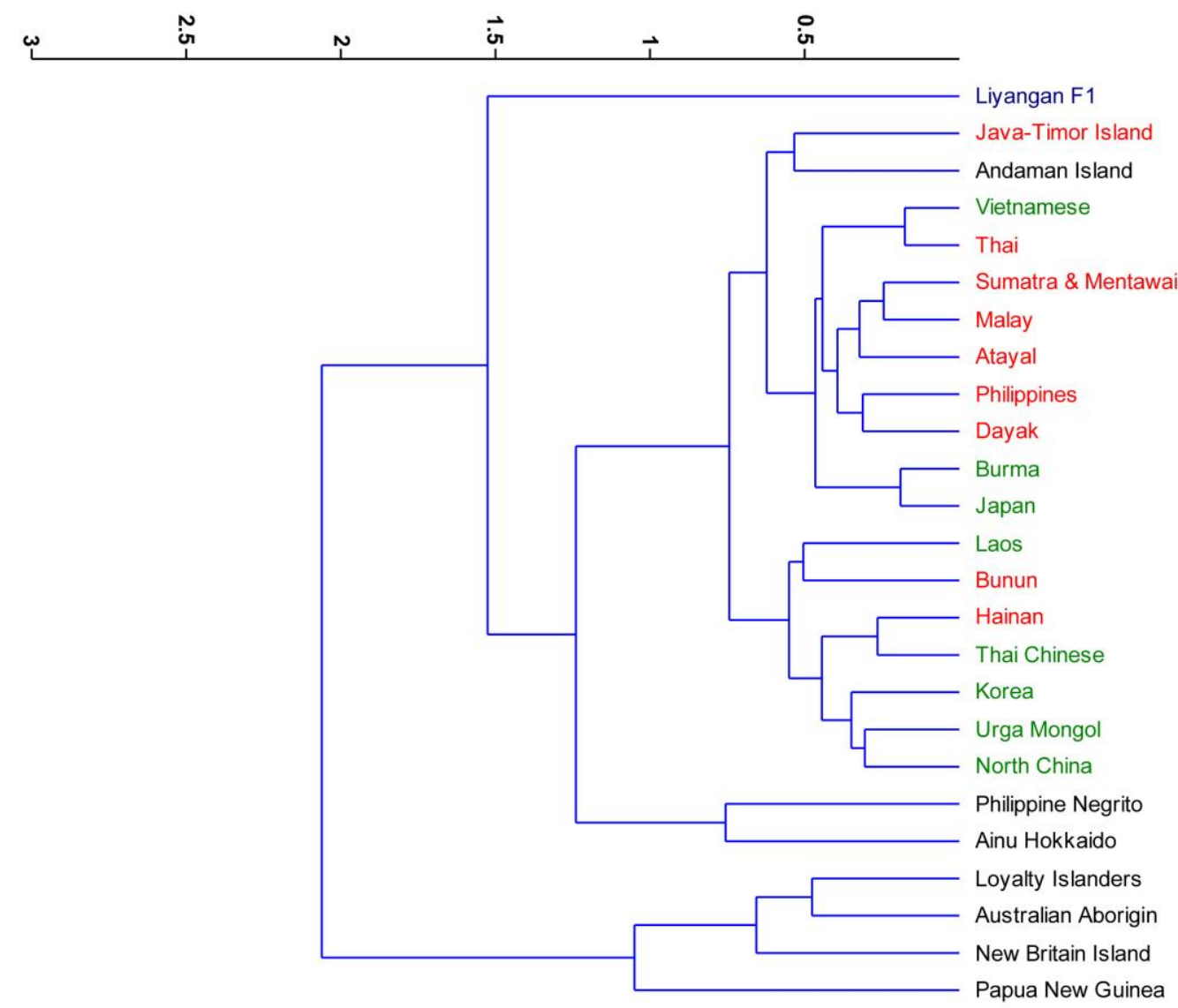

Gambar 9. Cluster Analysis Individu Liangan F1 Berdasarkan Morfometri $\mathrm{PM}^{3}-\mathrm{M}^{2}$

\section{Pola Hidup}

Aspek kultural yang dapat diobservasi pada individu Liangan F1 adalah tradisi pangur gigi yang ditunjukan oleh ablasi yang cukup ekstrim pada bidang occlusal, buccal dan lingual yang ditemukan pada empat gigi incisive atas dan bawah (Gambar 10). Dalam pengamatan dapat diketahui bahwa pangur pada bidang occlusal hanya ditemukan pada gigi incisive medial atas, sedangkan gigi incisive lateral atas yang berada di sebelahnya tidak terdapat jejak pangur pada bidang yang sama. Berdasarkan komposisi ini diperkirakan bahwa pangur pada bidang occlusal bertujuan untuk meratakan tinggi mahkota gigi sehingga terlihat sejajar.
Selain pangur pada bidang occlusal, hal yang sangat menarik adalah ditemukannya pangur gigi incisive pada bidang buccal dan lingual, sehingga gigi terlihat meruncing pada bidang occlusal. Belum dapat diketahui fungsi praktis dari pangur pada bidang buccal dan lingual ini. Kemungkinan besar, kedua jenis pangur ini berhubungan dengan aspek estetika yaitu agar pemilik gigi terlihat cantik menurut ukuran masyarakat Mataram Kuna di Liangan.

Kebiasaan pangur semacam ini pernah dijumpai pada masyarakat Jawa resen hingga beberapa puluh tahun yang lalu. Biasanya orang yang dipangur adalah perempuan remaja yang menginjak dewasa dan disertai dengan upacara atau ritual 
inisiasi. Berdasarkan pada analogi dengan data etnografi tersebut maka interpretasi ini juga memperkuat dugaan determinasi sex individu Liangan $\mathrm{F} 1$ yang diperkirakan memiliki jenis kelamin perempuan dan termasuk dalam rentang usia remaja mendekati dewasa muda.

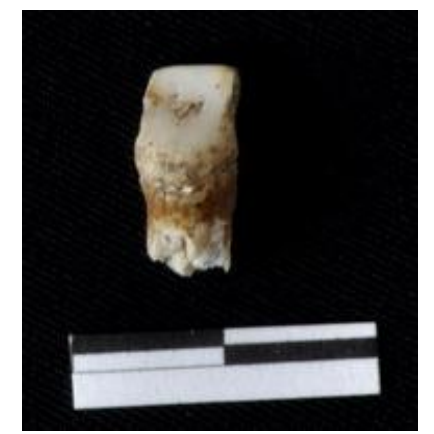

Gambar 10. Gigi incisive yang dipangur sisi buccalnya hingga bagian dentin (Dok. Balai Arkeologi Yogyakarta)

Selain itu, adanya penumpukan kapur pada bagian email yang merupakan patologi jenis dental kalkulus mungkin juga berhubungan dengan kebiasaan mengunyah sirih pinang yang dilakukan oleh individu Liangan F1. Kebiasaan mengunyah sirih pinang memang ditemukan di Jawa paling tidak sejak 3.200 tahun yang lalu hingga masa belakangan ini (Noerwidi, 2012). Biasanya, individu yang selama hidupnya memiliki kebiasaan mengunyah sirih pinang memiliki jejak warna merah pada bagian buccal dan lingual yang disebabkan oleh zat alkaloid (Rooney, 1993). Namun, dengan tidak adanya warna merah yang signifikan pada bagian email gigi individu Liangan F1 menyebabkan dugaan kebiasaan mengunyah sirih pinang perlu dibuktikan dengan analisis yang mendalam pada timbunan kapur tersebut.

\section{Prosesi Penguburan}

Sampai saat ini hanya ditemukan satu individu dari suatu konteks yang diduga kubur di situs Liangan. Berdasarkan data yang diperoleh maka diperkirakan bahwa individu Liangan F1 ditemukan dalam konteks kubur sekunder (penguburan kembali), karena dalam matriks tersebut hanya ditemukan tulang-tulang utama saja yaitu tengkorak dan tulang-tulang panjang. Hal yang menguatakan sebagai kubur sekunder adalah kondisi rangka yang berada dalam sebuah fitur dengan anggota tulang belulangnya tidak berada dalam suatu susunan anatomis. Tradisi penguburan berulang atau sekunder di Kepulauan Indonesia paling tidak telah dikenal sejak masa akhir prasejarah (Soejono, 1977).

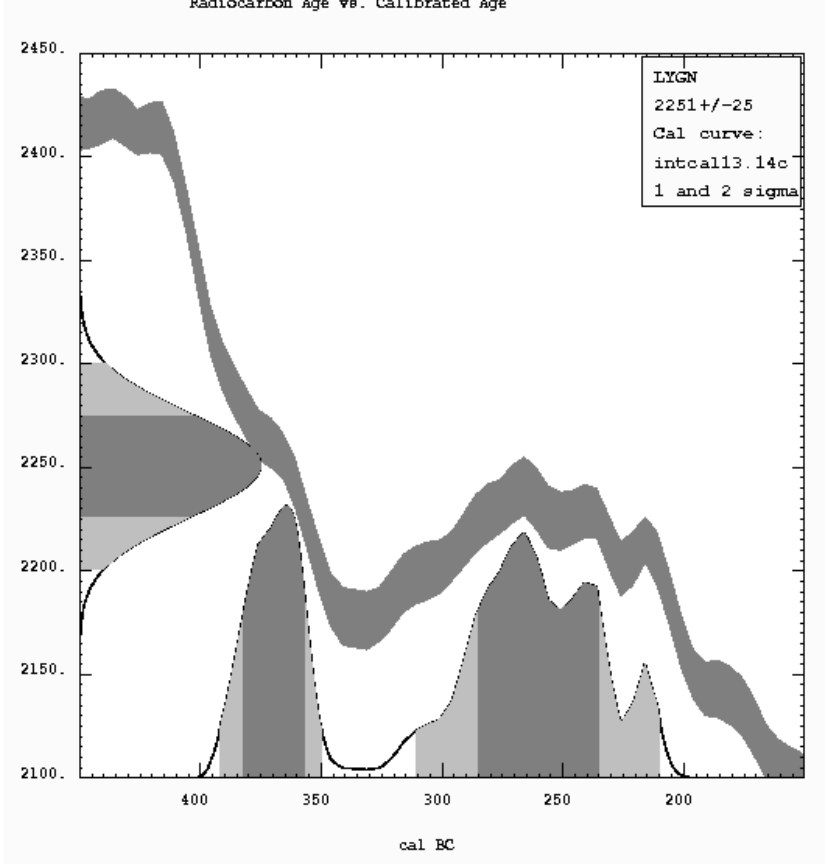

Gambar 11. Pertanggalan Fitur Kubur Individu Liangan F1 Berdasarkan Sampel Paleosoil (Dok. Tim Penelitian, 2014)

Berdasarkan hasil pertanggalan yang diperoleh dari fitur kubur Liangan $F 1$ diperoleh angka tahun $2231 \pm 25 \mathrm{BP}$, atau 
sekitar abad 2-3 Sebelum Masehi (Gambar 11). Pertanggalan ini menggunakan metode karbon konvensional (C14) dengan sample berupa paleosol (sedimen) dari dalam fitur kubur tersebut. Sampel dianalisis pada laboratorium pertanggalan PATIR-BATAN, Jakarta. Hasil pertanggalan ini jauh berbeda dengan hasil pertanggalan situs Liangan yang sebagian besar menunjukan angka tahun sekitar abad 9 - 10 Masehi atau masa kerajaan Mataram Kuna (Tim Penelitian, 2014). Adanya matriks tanah berumur 200-300 SM yang menyelimuti rangka manusia dari masa Klasik awal, memunculkan dugaan tentang tata cara penguburan. Ada kemungkinan bahwa angkota tulang-tulang utama individu Liangan F1 dikuburkan kembali pada sebuah lubang kubur setelah melewati proses penguburan pertama. Lubang kubur sekunder ini digali dengan menginvasi lapisan tanah yang yang lebih tua di bawahnya, sehingga ketika individu Liangan F1 dari abad $9-10 \mathrm{M}$ dikuburkan kembali bercampur dengan tanah berumur dari abad 2 $3 \mathrm{SM}$.

Selain itu, pada kubur tersebut juga ditemukan sebuah bekal kubur berupa buli-buli berukuran kecil (lebar $25 \mathrm{~mm}$ dan tinggi $26 \mathrm{~mm}$ ), berwarna putih yang berdasarkan hasil analisis keramologi berasal dari masa Dynasti T'ang (Gambar 12) (Tim Penelitian, 2014). Kondisi ini sangat menarik karena menunjukan bahwa pada masa Mataram Kuna yang telah terpengaruh budaya India (Hindu-Buddha), masih terdapat tradisi penguburan sekunder yang di Jawa telah muncul sejak periode prasejarah.

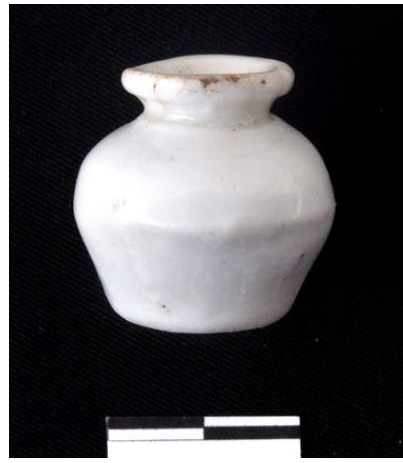

Gambar 12. Buli-buli masa Dinasti T'ang, bekal kubur individu Liangan F1 (Dok. Balai Arkeologi Yogyakarta).

\section{PENUTUP}

Di Indonesia, hingga saat ini belum banyak temuan rangka manusia dari periode klasik (HinduBuddha) abad V - XV Masehi. Sedikitnya temuan rangka manusia dari masa ini mungkin disebabkan oleh proses tafonomi kultural yang kurang mendukung terpreservasinya data tersebut. Dengan penemuan Balai Arkeologi Yogyakarta tahun 2013 ini membuat sisa manusia dari situs Liangan memiliki kedudukan yang cukup penting untuk mengungkap aspek biokultural kehidupan masyarakat pada masa Mataram Kuna di Jawa.

Berdasarkan hasil analisis bioarkeologi yang telah dilakukan dalam penelitian ini dapat diketahui bahwa rangka Liangan F1 adalah individu perempuan yang berumur sekitar 18-22 tahun. Individu ini memiliki ciri rasial Mongoloid yang kuat dengan beberapa campuran karakter Australo-Melanesoid. Perempuan muda tersebut mengidap beberapa penyakit periodontal dan mengalami modifikasi gigi yang berhubungan dengan aspek estetika. Individu Liangan F1 dimakamkan pada suatu konteks kubur sekunder yang hanya melibatkan beberapa anggota tulang utamanya saja. 
Analisis bioarkeologi pada sisa rangka manusia Liangan $\mathrm{F} 1$ belum dapat dilakukan secara maksimal. Hal ini disebabkan oleh sifat temuan yang sangat fragmentaris dan keterbatasan penguasaan beberapa teknik analisis yang saat ini tidak dapat dilakukan oleh instansi arkeologi. Analisis yang signifikan untuk dilakukan pada masa mendatang adalah direct dating melalui teknik AMS dengan pengambilan sampel langsung pada tulang belulang individu tersebut. Teknik pertanggalan langsung ini berguna untuk mengkonfirmasi kronologi budaya individu Liangan F1 yang berada pada konteks situs permukiman masa Mataran Kuna. Selain itu analisis genetik juga signifikan untuk dilakukan guna mengungkap lebih dalam keterkaitan antara individu Liangan F1 dengan populasi kuna dan resen di Jawa serta kawasan di sekitarnya yang relevan.

\section{UCAPAN TERIMA KASIH}

Penulis mengucapkan terima kasih sebesar-besarnya kepada Drs. Sugeng Riyanto, M.Hum, selaku ketua Tim Penelitian Arkeologi di situs permukiman Mataram Kuna - Liangan, Kab. Temanggung, Jawa Tengah atas izin yg diberikan untuk menganalisis sisa rangka manusia tersebut.

Penghargaan yang tinggi juga disampaikan kepada dua orang rekan di Balai Arkeologi Yogyakarta: Z. Dekon Suyanto atas bantuannya selama penulis melakukan pekerjaan laboratorium, dan kepada Andreas Eka Atmaja atas bantuannya dalam membuat beberapa dokumentasi foto yang digunakan dalam tulisan ini. 


\section{DAFTAR PUSTAKA}

Enoki K., Dahlberg A.A. 1958. "Rotated maxillary central incisors", Orthod J Jpn 17, pp. 157.

Hanihara K., Tanaka T., Tamada M. 1970. "Quantitative analysis of the shovelshaped character in the incisors", J Anthropol Soc Nippon 78, pp. 90-93.

Holland, S.M. 2006. Cluster Analysis. University of Georgia

Jørgensen K.D. 1955. "The Dryopithecus pattern in recent Danes and Dutchmen", J Dent Res 34, pp. 195-208.

Lovejoy, C.O. 1985. "Dental wear in the Libben population: Its functional pattern and role in the determination of adult skeletal age at death. American Journal of Physical Anthropology 68. pp. 47-56.

Matsumura, H. dan Oxenham, M.F. 2014. Demographic Transitions and Migration in Prehistoric East/Southeast Asia Through the Lens of Nonmetric Dental Traits,

Noerwidi, Sofwan. 2012. "The significant of the Holocene human skeleton Song Keplek 5 in the history of human colonization of Java: A comprehensive morphological and morphometric study", International Master Thesis in Quaternary and Prehistory, Paris: MNHN

Rangkuti, Nurhadi. dan Tjahjono, Baskoro. D. 2000. "Laporan Peninjauan Situs Liyangan, Temanggung, Laporan Penelitian, Yogyakarta: Balai Arkeologi

Riyanto, S. 2011. "Integrasi Data, Gambaran Rekonstruktif, dan Kronologi Situs Liyangan", Berita Penelitian Arkeologi No. 25, Yogyakarta: Balai Arkeologi, pp. 45-61

2012. "Kawasan Situs Liyangan: Luasan, Bentuk, Ragam Komponen Permukiman, serta Hubungan Fungsional antar Komponen dan Ruangnya", Berita Penelitian Arkeologi No. 25, Yogyakarta: Balai Arkeologi, pp. 60-72

Rooney, D.F. 1993. Betel Chewing Traditions in South-East Asia, Oxford: University Press

Saheki M. 1958. "On the heredity of the tooth crown configuration studied in twins", Acta Anat Nipponica 33, pp. 456-470.

Scott, G.R. 1973. "Dental morphology: A genetic study of American White families and variation in living Southwest Indians". PhD dissertation, Arizona State University

Soejono, R.P. 1977. "Sistem-sistem penguburan pada akhir masa prasejarah di Bali", Doctoral Thesis, University of Indonesia 
Suzuki M. dan Sakai T. 1973. The Japanese dentition, Matsumoto: Shinshu Univ Press.

Tim Penelitian. 2013. "Laporan Penelitian Arkeologi: Situs Liangan, Temanggung, Jawa Tengah", Laporan Penelitian Arkeologi, Yogyakarta: Balai Arkeologi

2014. "Laporan Penelitian Arkeologi: Situs Liangan, Temanggung, Jawa Tengah", Laporan Penelitian Arkeologi, Yogyakarta: Balai Arkeologi

Turner CG II, Nichol CR, Scott GR. 1991. "Scoring procedures for key morphological traits of the permanent dentition: The Arizona State University dental anthropology system", dalam Kelly M.A., Larsen C.S., eds., Advances in dental anthropology, New York: Wiley-Liss, pp. 13-31.

White, T.D. dan Folkens, P.A. 2005. The Human Bone Manual. United Kingdom: Elsevier, Inc. 